\title{
Temporal variation in the symbiosis and growth of the temperate scleractinian coral Astrangia poculata
}

\author{
J. Dimond ${ }^{1,2, *}$, E. Carrington ${ }^{1,3}$ \\ ${ }^{1}$ Department of Biological Sciences, University of Rhode Island, 100 Flagg Rd., Kingston, Rhode Island 02881, USA \\ ${ }^{2}$ Present address: Marine Biological Laboratory, 7 MBL St., Woods Hole, Massachusetts 02543, USA \\ ${ }^{3}$ Present address: Department of Biology and Friday Harbor Laboratories, University of Washington, 620 University Rd., \\ Friday Harbor, Washington 98250, USA
}

\begin{abstract}
Seasonal variation in the algal symbiosis and growth of Astrangia poculata, a facultatively symbiotic temperate scleractinian, was explored in Rhode Island, USA. Coral pigmentation and growth were measured simultaneously and repeatedly in both zooxanthellate (corals with symbionts) and azooxanthellate (symbiont free) colonies at 2 sites ( $10 \mathrm{~km}$ apart) over a 15 mo period using nondestructive digital image analysis methods. A chlorophyll density proxy based on coral pigmentation was derived from multivariate analysis of color data from coral images, and polyps were enumerated to measure colony growth. Among zooxanthellate corals, predicted chlorophyll density exhibited significant seasonal fluctuations that were positively related to temperature, with maxima occurring during late summer and early autumn. Pigmentation dynamics in azooxanthellate corals were more variable, although many of these corals displayed temporal fluctuations in pigmentation. Growth also exhibited seasonal fluctuations positively related to temperature, and ceased during the coldest 3 to 4 mo of the year. Corals lost live polyps during the winter as a result of tissue thinning and dormancy, which rendered the colony unable to fend off settling organisms. Although zooxanthellate colonies were able to grow faster than azooxanthellate colonies, coral pigmentation explained only $23 \%$ of the variation in growth rate, emphasizing the importance of heterotrophy as the primary source of nutrition for $A$. poculata at this northern margin of its range.
\end{abstract}

KEY WORDS: Temperate coral · Astrangia · Coral-Algal symbiosis · Seasonal variation · Scleractinian · Coral growth $\cdot$ Zooxanthellae

\section{INTRODUCTION}

Endosymbiotic mutualisms with dinoflagellates of the genus Symbiodinium, algal cells more commonly known as zooxanthellae, are widespread among scleractinian corals. For reef-building tropical corals, this association provides the bulk of the coral's nutrition via translocation of zooxanthella photosynthetic products (Muscatine 1990). Scleractinians at high latitudes do not build reefs and are not as diverse or abundant as they are in the tropics, but many of them do maintain relationships with zooxanthellae (Shuhmacher \& Zibrowius 1985). However, unlike tropical coral-zooxanthella relationships, tem- perate associations tend to be facultative rather than obligate, meaning that they can persist both with and without notable symbiont populations. Several factors contribute to the reduced prevalence of this symbiosis at high latitudes relative to the tropics, including reduced irradiance for photosynthesis (Weston 1980, Miller 1995), limited input from zooxanthellae to coral calcification and energetic demands under lower temperature and irradiance (Jacques et al. 1983), and an environment that inherently selects for competitively superior macroalgae over corals in well-lit areas due to low grazing pressure and high nutrient concentrations (Miller \& Hay 1996, Grace 2004). In spite of this, some temperate scleractinians 
commonly maintain Symbiodinium populations as dense as tropical corals (Jacques et al. 1983, Schiller 1993).

Coral-Symbiodinium symbioses are dynamic. Recent studies on tropical corals have shown that symbiotic zooxanthella populations undergo regular fluctuations that are responses to environmental factors, including seasonal temperature and light cycles and variations in dissolved inorganic nutrient concentrations (Stimson 1997, Brown et al. 1999, Fagoonee et al. 1999, Fitt et al. 2000, Costa et al. 2005). These fluctuations in algal density correlate with photosynthetic capacity (Warner et al. 2002), which may ultimately drive tissue biomass cycles (Fitt et al. 2000). Thus, while recognizing that corals can actively regulate the population density of their symbionts (Baghdasarian \& Muscatine 2000), the extrinsic environment is a fundamental determinant of zooxanthella dynamics and, ultimately, coral physiology and growth. Little is known, however, about how coral-zooxanthella symbioses vary seasonally in temperate seas that experience reduced irradiance, colder temperatures, and greater seasonal variation in environmental conditions than do tropical regions. It has been suggested that zooxanthella symbioses in sea anemones are seasonally more stable at high latitudes than in the tropics (Muller-Parker \& Davy 2001), but this hypothesis has not been evaluated with anemones or corals. Latitudinal comparisons of cnidarian-zooxanthella symbioses in general are therefore incomplete without an understanding of the long-term field ecology of temperate associations (Muller-Parker \& Davy 2001). Ultimately, such comparisons help place the ecology of both temperate and tropical associations within a broader context, considering the full range of cnidarian and Symbiodinium adaptations.

Astrangia poculata (= A. danae, Peters et al. 1988) is a small facultatively symbiotic coral found both azooxanthellate and zooxanthellate to varying degrees in shallow coastal waters along the northwest Atlantic, reaching its northern limit around Cape Cod. Zooxanthellae are obtained post-settlement rather than from preceding generations (Szmant-Froelich et al. 1980), suggesting that all corals have equal ability to host symbionts. Although there is considerable overlap in the distribution of zooxanthellate and azooxanthellate colonies, irradiance plays a key role in determining the extent of symbiosis in this coral, limiting it to depths receiving 80 to $90 \%$ of the surface irradiance (Weston 1980). The facultative nature of symbiosis in A. poculata has been useful for several studies investigating the influence of symbionts on coral nutrition (SzmantFroelich \& Pilson 1980, 1984), calcification and metabolism (Jacques \& Pilson 1980, Jacques et al. 1983, Cummings 1983), recovery from sedimentation (Peters
\& Pilson 1985), and paleotemperature estimates (Cohen et al. 2002), but there is limited information on temporal, spatial, or within-individual dynamics of symbiosis and growth in natural settings (but see Cummings 1983).

The present study investigated the symbiosis and growth of zooxanthellate and azooxanthellate Astrangia poculata colonies over a $1 \mathrm{yr}$ period in Rhode Island, USA. Seasonal dynamics of growth and symbiosis were compared at 2 sites with different physical regimes in order to evaluate the relative importance of spatial versus temporal effects and potential abiotic influences, including temperature and irradiance. In order to make repeated measurements and to measure symbiosis and growth simultaneously in this small coral, it was necessary to use non-destructive photographic methods to estimate chlorophyll density (Edmunds et al. 2003).

\section{MATERIALS AND METHODS}

Experimental design. A field experiment was conducted for 15 mo (14 May 2004 to 23 July 2005) at 2 sites in Rhode Island, USA: an open bay site in Ft. Wetherill State Park in Jamestown (FW; $41^{\circ} 28^{\prime} 40^{\prime \prime} \mathrm{N}$, $\left.71^{\circ} 21^{\prime} 34^{\prime \prime} \mathrm{W}\right)$, and a tidal river site approximately $10 \mathrm{~km}$ to the southwest, in the lower Pettaquamscutt River ( $\left.\mathrm{PR}_{i} 41^{\circ} 26^{\prime} 55^{\prime \prime} \mathrm{N}, 71^{\circ} 26^{\prime} 58^{\prime \prime} \mathrm{W}\right)$ in Narragansett. Ft. Wetherill is a rocky point with moderate exposure to wave-action at the extreme southern end of Narragansett Bay, facing Rhode Island Sound. The Pettaquamscutt River is $10 \mathrm{~km}$ in length and averages $2 \mathrm{~m}$ deep, draining a 3634 ha watershed into western Rhode Island Sound. At both sites, 7 plots of approximately $25 \mathrm{~cm}^{2}$ were cleared of algae and other organisms on southwest-facing vertical rock surfaces at $3 \mathrm{~m}$ depth below mean low low water. Plots were spaced approximately $50 \mathrm{~cm}$ apart and spanned a horizontal length of about $5 \mathrm{~m}$.

A reciprocal transplant design was employed to control for the possibility that corals from these 2 sites were inherently different from each other with respect to their growth or ability to host symbionts. Four Astrangia poculata colonies were placed in each plot: zooxanthellate and azooxanthellate individuals native to the site and zooxanthellate and azooxanthellate individuals collected from the opposite site. Sample size was thus 14 corals of each symbiotic state at each site (56 corals total). Initial symbiotic state was visually estimated during collection; unpigmented corals were considered azooxanthellate, and corals with complete brown tissue pigmentation were considered zooxanthellate. Corals were collected with hammer and chisel from $3 \mathrm{~m}$ depth near the cleared plots, then haphaz- 
ardly reattached to the vertical substrate using underwater epoxy (Kop-Koat A-788) and marked with uniquely numbered aluminum tags glued beneath. Eight corals at PR were lost after the start of the study in May 2004; since this was early in the study, these were subsequently replaced in June 2004 with new individuals. Six other corals (3 at each site) were lost in various stages during the study, but were not replaced. Plots were periodically maintained by removing macroalgal recruits to ensure that unobstructed photographs could be taken and corals were not exposed to algal competition. Relieving corals from algal interference also reduced variability in the light environment.

Digital photography and image analysis. Approximately monthly (until January 2005, after which sampling occurred approximately every other month), all corals were individually photographed with a 4megapixel Olympus C-4000 digital camera set manually in macro-setting with full internal flash, aperture of 2.8, and shutter speed of 1/60. All corals were photographed with their polyps withdrawn so that individual polyps could be seen and to avoid any effects of polyp expansion on image analysis; this was accomplished by lightly touching each coral before the image was taken. A metal framer attached to the camera housing ensured that images were captured from a fixed distance of $14 \mathrm{~cm}$ and that the coral was always positioned for optimal lighting. Two sets of red, green, and blue (RGB) electrical tape bands wrapped around $1.5 \mathrm{~cm}$ diameter PVC tubing were attached to the end of the framer such that the coral being photographed was surrounded by these bands. The bands were used to standardize the RGB brightness of all images in subsequent image analyses (Edmunds et al. 2003), as described below.

SigmaScan Pro 5 (SPSS) image analysis software was used to measure coral pigmentation. For every coral image, each individual polyp was outlined using the trace tool, which automatically recorded the red, green, and blue brightness into a spreadsheet. Tracing each polyp rather than the whole coral was necessary to avoid capturing pigmentation between polyps from the bare skeleton or the often abundant red or green endolithic algae. Polyp RGB values were then averaged. To reduce variation attributed to differences in image exposure and brightness, the average polyp RGB was standardized relative to all images in the dataset (every image from all sites and sampling dates) by subtracting the pooled average RGB values of the RGB tape bands on the framer present in all images. Principal component analysis (PCA) on a correlation matrix (complete analysis performed by SYSTAT v.11, SYSTAT) of the standardized polyp RGB values was used to generate a single variable that explained a large proportion of the variance (Edmunds et al. 2003). This unit-less principle component was dubbed 'polyp color' and multiplied by -1 to make the directionality of the values more intuitive (i.e. the more symbiont pigments, the more positive the polyp color value). Polyp color values were then adjusted relative to the lowest value in the dataset by adding the positive integer of the lowest value, such that the lowest value became zero. For example, the lowest polyp color value was -4.121 , so 4.121 was added to all values.

Establishing a chlorophyll density proxy. Since Astrangia poculata has no host pigments and is translucent white when azooxanthellate, the intensity of brown pigmentation in a coral colony is directly related to the density of Symbiodinium pigments. Chlorophyll was chosen over zooxanthella density as a symbiosis parameter because zooxanthellae undergo seasonal fluctuations in pigment concentration related to photoadaptation (Cummings 1983, Fitt et al. 2000), and therefore any correlation between zooxanthella density and coral color would not be consistent over time. To quantify the relationship between coral color and algal pigments, 20 corals of varying symbiotic status were photographed in situ in September 2004 using the methods described above, then immediately brought back to the laboratory for chlorophyll analysis. Colony tissue was removed using a Waterpik (Johannes \& Wiebe 1970), then homogenized in a blender. Aliquots (60 to $70 \mathrm{ml}$ ) were centrifuged, and the resulting pellet was resuspended in $4 \mathrm{ml}$ of $100 \%$ acetone for $24 \mathrm{~h}$ of extraction at $4^{\circ} \mathrm{C}$. After centrifugation, the extract was analyzed for chlorophylls $a$ and $c_{2}$ using a Spectronic Genesys spectrophotometer and equations from Jeffrey \& Humphrey (1975). Total chlorophyll concentrations were expressed in terms of coral surface area by using the aluminum foil method of Marsh (1970). RGB color data from these 20 corals that were processed for their chlorophyll content were standardized, along with the field study dataset, and were included in the overall PCA so that their polyp color values would be computed relative to all samples in the field study. This allowed conversion of polyp color values to predicted chlorophyll density using the regression curve.

Measuring coral growth. Although the Astrangia poculata colonies chosen for the present study were encrusting in morphology, polyp number was the chosen measure of growth over colony area because it was assumed to better capture the often 3-dimensional growth of a colony, and it proved to be a more useful measure of live colony surface during the cold season when corals were dormant and other organisms encroached on or near their skeletons. Only living polyps with obvious tissue presence were counted. Daily growth rates between sampling points were 
calculated by dividing the number of polyps accumulated from one sampling date to the next by the number of days in that period.

Environmental data. Light and temperature were recorded with data loggers (Onset Computers) moored at $3 \mathrm{~m}$ depth adjacent to experimental plots at each site. Hobo HLI light intensity loggers (spectral response $=300$ to $1100 \mathrm{~nm}$ ) encased in cylindrical transparent polycarbonate housings recorded luminous flux (lumens $\mathrm{m}^{-2}$ ) at 30 min intervals during most of the summer of 2004, providing a measure of relative light differences between the 2 sites. Due to excessive fouling of light logger housings by sediment and organisms after approximately $10 \mathrm{~d}$ of immersion, only the first $9 \mathrm{~d}$ of light data were utilized. Since light loggers were exchanged and downloaded approximately monthly over the course of the summer, three $9 \mathrm{~d}$ periods were used for analysis of a total of $27 \mathrm{~d}$. Maximum and cumulative daily light intensity were computed in order to compare the light environment at the 2 sites, and differences were evaluated with a paired $t$-test.

Temperature was logged year-round every $10 \mathrm{~min}$ with Stowaway TidBit devices $\left( \pm 0.5^{\circ} \mathrm{C}\right.$ accuracy). Temperature loggers at FW were lost during most of the summer of 2004 (18 June 2005 to 8 September 2005); the gap in the time series was filled with data from nearby NOAA CO-OPS Weather Station 8452660 in Newport, RI (www.tidesandcurrents.noaa. gov; $\left.41^{\circ} 30^{\prime} 20^{\prime \prime} \mathrm{N}, 71^{\circ} 19^{\prime} 35^{\prime \prime} \mathrm{W}\right)$. The Newport station data were adjusted to predicted FW values with a linear equation obtained through regression analysis of warm season periods for which both Newport and FW data were available (September 2004 and June/ July $2005 ; y=1.1 x-2.6 ; \mathrm{R}^{2}=0.87$ ). Monthly means were computed for the 15 mo of temperature records, and a paired $t$-test was used to examine differences in the mean temperature between sites.

Local water-level data for a $6 \mathrm{~d}$ period between 14 and 20 May 2004 were obtained from the NOAA weather station in Newport. These hourly data were used to examine the potential influence of tidal rhythms on light and temperature conditions at the study sites. Cross-correlation analyses were employed to analyze the relationship between tide and temperature.

Statistical analyses. Multivariate analysis of variance (MANOVA) was used to perform repeated-measures analyses of both predicted chlorophyll and growth data, with month as the repeated factor. SYSTAT v.11 (SYSTAT Inc.) was used for these analyses. Parametric assumptions were met with a $\log (x+1)$ transformation for predicted chlorophyll data and a $\log (x+2)$ transformation for growth data. One-way MANOVAs testing collection site as the factor found no significant differ- ences in predicted chlorophyll $(\mathrm{df}=1, F=0.239, \mathrm{p}=$ 0.627 ) or growth ( $\mathrm{df}=1, F=1.148, \mathrm{p}=0.289$ ) based on collection site. Subsequently, both datasets were analyzed with 2-way MANOVAs, with site and symbiotic state as factors. To avoid unbalanced analyses due to corals lost during the study, a total of 47 missing values ( $7 \%$ of predicted chlorophyll data and $7.6 \%$ of growth data) was replaced with treatment means. The degrees of freedom and mean squares for the error terms of the within-subjects components of these tests were adjusted accordingly (Underwood 1997).

\section{RESULTS}

\section{Chlorophyll density proxy}

PCA of the RGB color values yielded a single principal component (polyp color) that explained $93.5 \%$ of the variance. Component loadings for red, green, and blue variables were $0.951,0.978$, and 0.971 , respectively, indicating a strong and largely equal contribution of each variable to the principal component. The relationship between polyp color and total chlorophyll density was non-linear, best described by a polynomial function $\left(y=0.044 x^{2}+0.0335 x_{i} R^{2}=0.89 ;\right.$ Fig. 1$)$. The curvilinear shape of the function suggests that estimates of chlorophyll are least reliable at low polyp color values, but improve in accuracy with increasing pigmentation, as shown by $95 \%$ prediction limits (Fig. 1). Prediction limits indicate the $95 \%$ probability of data from a subsequent experiment falling within

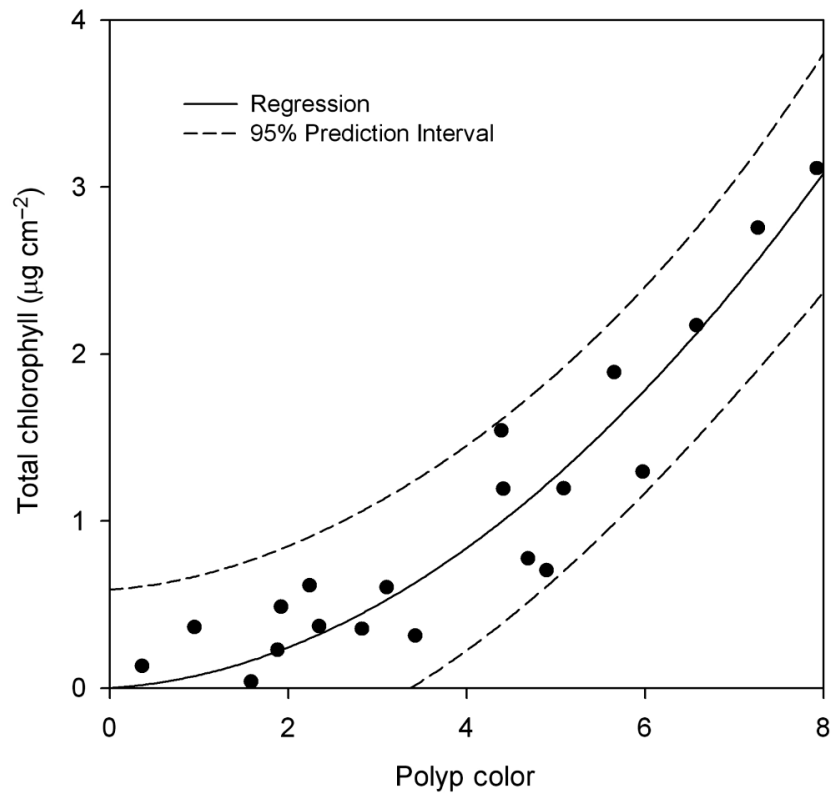

Fig. 1. Astrangia poculata. Relationship between polyp color and areal chlorophyll $\left(\mathrm{n}=20 ; y=0.044 x^{2}+0.0335 x ; \mathrm{R}^{2}=0.89\right)$ 
the given range. In spite of potential inaccuracies, temporal patterns were largely non-random, and 3 out of 4 time series showed significant autocorrelation coefficients (FW zooxanthellate $=0.633$; FW azooxanthellate $=0.569$; PR azooxanthellate $=0.6781$ ), with PR zooxanthellate corals having the lowest coefficient (0.394).

\section{Environmental parameters}

Temperature and light data show that the physical environment at the 2 sites was not similar (Fig. 2). Temperatures at both sites were negatively correlated with tidal height, and cross-correlation analyses revealed that the highest Pearson correlation coefficients were associated with a $3 \mathrm{~h}$ lag at PR (-0.714) and a $1 \mathrm{~h}$ lag at FW (-0.353), meaning that temperatures peaked approximately 3 and $1 \mathrm{~h}$ after Newport low tide, respectively. The time lag is consistent with field observations, whereby an ebb tide was often encountered at PR when FW was already in flood phase. Light intensity at PR underwent regular reductions during the same low tide periods when temperatures changed most dramatically. At FW, temperature and light levels did not exhibit drastic responses to tidal fluctuations.

Cumulative and maximum daily light intensity were significantly different between the 2 sites (paired $t$-tests, $\mathrm{p}=0.016$ and 0.027 , respectively), whereby FW had significantly higher light values than PR. The differ- ence in cumulative daily light between sites suggests that, on average, PR received $25 \%$ less light per day than FW. However, as with temperature, the light environment at PR was highly variable, and some days were characterized by higher maximum and total light at PR than at FW.

Monthly mean temperatures for the year were also significantly different $\left(\mathrm{FW}=11.9 \pm 1.6^{\circ} \mathrm{C} ; \mathrm{PR}=13.0 \pm\right.$ $1.8^{\circ} \mathrm{C}$; paired $t$-test, $\left.\mathrm{p}=0.024\right)$, with $\mathrm{PR}$ just over $1^{\circ} \mathrm{C}$ warmer than FW (Fig. 3A). PR was also characterized by the broadest and most variable temperature regime, with a range of $28.6^{\circ} \mathrm{C}$, while $\mathrm{FW}$ had a range of $23.8^{\circ} \mathrm{C}$. Both warming in the spring and cooling in the fall occurred sooner at $\mathrm{PR}$, and, in general, PR was warmer in spring and summer, but cooler in fall and winter, sometimes differing from FW by $>5^{\circ} \mathrm{C}$. Based on physiological data from Jacques et al. (1983), Astrangia poculata calcification is affected by 2 key temperature thresholds: $6.5^{\circ} \mathrm{C}$, the approximate temperature at which calcification was measurable, and $15^{\circ} \mathrm{C}$, the approximate temperature at which zooxanthellae had a measurable effect on coral calcification. Analysis of average daily temperatures between 15 May 2004 and 14 May 2005 showed that, while the $6.5^{\circ} \mathrm{C}$ threshold was exceeded for nearly the same amount of time at both sites (256 and $260 \mathrm{~d}$ at FW and PR, respectively), the $15^{\circ} \mathrm{C}$ threshold was exceeded for $22 \mathrm{~d}$ longer at PR (129 and $151 \mathrm{~d}$ at FW and PR, respectively).
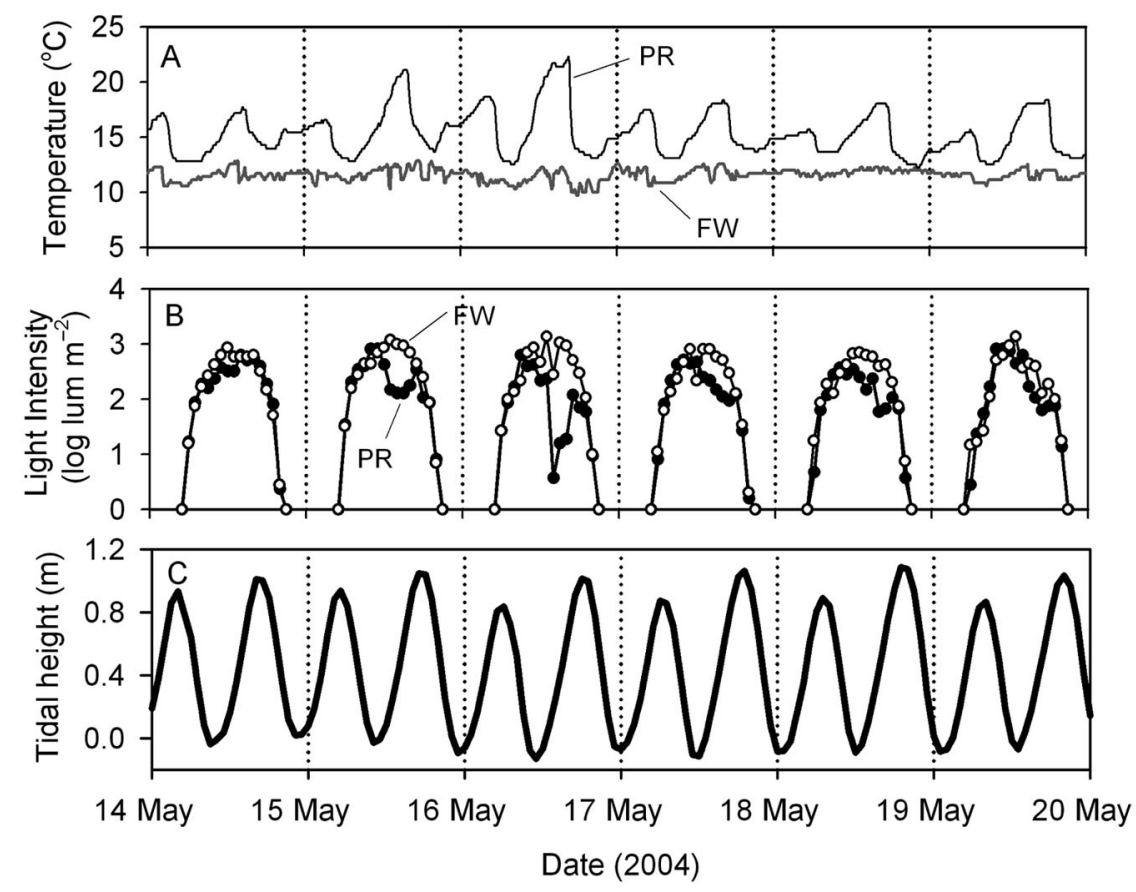

Fig. 2. (A) Temperature and (B) light conditions at the study sites (PR and FW) in reference to (C) tidal rhythms at the Newport NOAA CO-OPS station from 14 to 20 May 2004 


\section{Seasonal patterns of symbiosis and growth}

Although the seasonal trends of predicted chlorophyll density were significantly different between zooxanthellate and azooxanthellate corals (Table 1, Fig. 3B), pigmentation in both types of corals was dynamic. Pigmentation in zooxanthellate corals increased from starting levels in May (but note initial drop at FW) before reaching a peak in late summer/ early autumn, then decreased and stabilized somewhat during the winter. The temporal response of initially azooxanthellate corals ranged from nearly zero accumulation of pigmentation to complete changes whereby all polyps in a colony became fully symbiotic at some point during the year-long study. In fact, only 3 out of 27 azooxanthellate corals did not gain noticeable pigmentation. A significant difference between sites (Table 1, Fig. 3B) is particularly evident
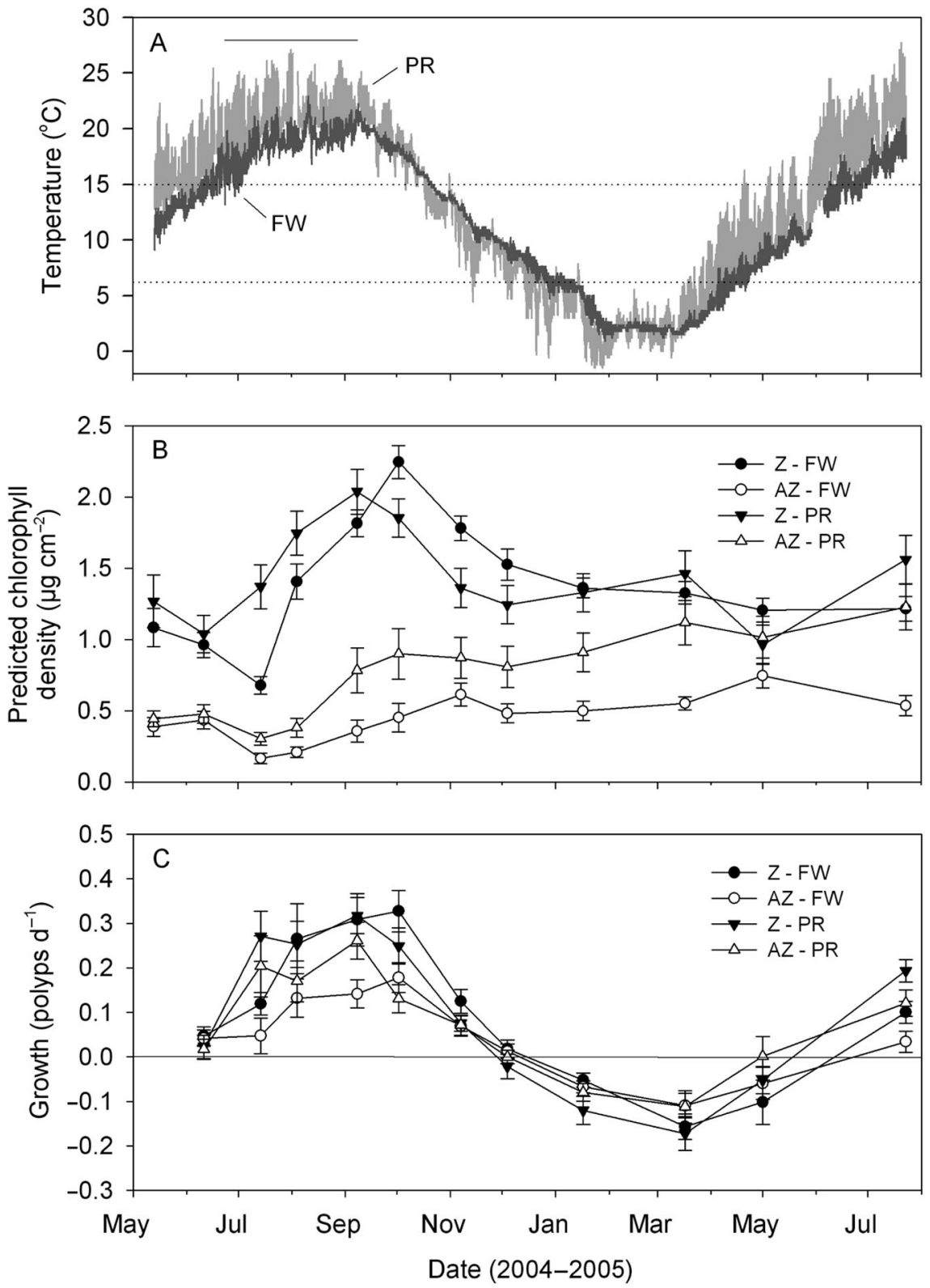

Fig. 3. Astrangia poculata. (A) Temperatures (3 $\mathrm{m}$ depth) at Pettaquamscutt River (PR, light gray) and Ft. Wetherill (FW, dark gray) during the study period. Solid horizontal line indicates the period for which adjusted NOAA CO-OPS station data were substituted for lost data loggers at FW. Dotted horizontal lines indicate the physiologically important temperature thresholds delineated by Jacques et al. (1983): $6.5^{\circ} \mathrm{C}$, the temperature above which calcification was measurable, and $15^{\circ} \mathrm{C}$, the temperature above which symbiosis had a measurable effect on calcification. (B) Mean ( \pm SE) predicted chlorophyll density of corals over time.

(C) Mean $( \pm \mathrm{SE})$ growth rate of corals over time. Z: zooxanthellate corals; AZ: azooxanthellate corals 
Table 1. MANOVA results for predicted chlorophyll density. Sym: the initial symbiotic state of corals

\begin{tabular}{|lrcrr|}
\hline Source & df & MS & $F$ & \multicolumn{1}{c|}{$p$} \\
\hline Between subjects & & & & \\
Site & 1 & 1.45 & 5.448 & 0.023 \\
Sym & 1 & 28.43 & 106.8 & $<0.001$ \\
Site $\times$ Sym & 1 & 1.028 & 3.862 & 0.055 \\
Error & 52 & 0.266 & & \\
Within subjects & & & & \\
Month & 11 & 0.632 & 31.99 & $<0.001$ \\
Month $\times$ Site & 11 & 0.107 & 5.426 & $<0.001$ \\
Month $\times$ Sym & 11 & 0.420 & 21.29 & $<0.001$ \\
Month $\times$ Site $\times$ Sym & 11 & 0.097 & 4.923 & $<0.001$ \\
Error & 525 & 0.021 & & \\
\hline
\end{tabular}

among azooxanthellate corals. Although azooxanthellate corals at both sites exhibited an increase in pigmentation, PR coral pigmentation increased substantially more than at FW. Among zooxanthellate corals, there was a 1 mo difference in the timing of maximum coral pigmentation between sites, with PR corals reaching their peak before FW corals.

Coral growth also underwent significant seasonal variation, but did not differ significantly between sites (Table 2, Figs. 3C \& 4). However, growth differed significantly depending on initial symbiotic state, with zooxanthellate corals growing significantly more than azooxanthellate corals. The majority of polyp growth occurred in the 8 mo between May and December. In the winter and early spring, many corals substantially declined in live polyp number due to tissue loss. This loss, unlike the growth that occurred under warmer conditions, affected both types of corals similarly. Apparently, corals cease feeding and contract their polyps during this period (Jacques et al. 1983, J.D.
Table 2. MANOVA results for daily growth rate. Sym: the initial symbiotic state of corals

\begin{tabular}{|lrccc|}
\hline Source & df & MS & $F$ & $p$ \\
\hline Between subjects & & & & \\
Site & 1 & 0.010 & 2.074 & 0.156 \\
Sym & 1 & 0.038 & 8.252 & 0.006 \\
Site $\times$ Sym & 1 & 0.007 & 1.543 & 0.220 \\
Error & 52 & 0.005 & & \\
Within subjects & & & & \\
Month & 10 & 0.224 & 65.02 & $<0.001$ \\
Month $\times$ Site & 10 & 0.013 & 3.770 & $<0.001$ \\
Month $\times$ Sym & 10 & 0.013 & 3.787 & $<0.001$ \\
Month $\times$ Site $\times$ Sym & 10 & 0.001 & 0.235 & 0.993 \\
Error & 520 & 0.004 & & \\
\hline
\end{tabular}

pers. obs.), which renders them more susceptible to sedimentation stress (Peters \& Pilson 1985) and algal overgrowth. This is compounded by tissue thinning that reduces the coenosarc to nearly nothing, essentially removing connectivity between polyps and opening up bare skeleton for the recruitment of algae, barnacles, and other organisms (J.D. pers. obs.). Despite this loss, tissue and skeletal growth resumed between the final 2 sampling periods in May and July 2005.

Based on linear regression analysis of polyp color and daily coral growth rates averaged for the major period of coral growth (May to December), predicted chlorophyll density explained $23 \%$ of the variation in coral growth ( $\mathrm{n}=56, y=0.0586 x+0.0888, \mathrm{R}^{2}=0.23, \mathrm{p}<0.001$; Fig. 5). Growth was highly temperature dependent (ANCOVA, $\mathrm{p}<0.001$ ), and zooxanthellate coral growth was more strongly influenced by temperature than growth in azooxanthellate corals (ANCOVA, temperature $\times$ symbiotic state, $\mathrm{p}<0.003)$, particularly at the higher range of temperatures (Fig. 6). Plotted on similar linear scales, the

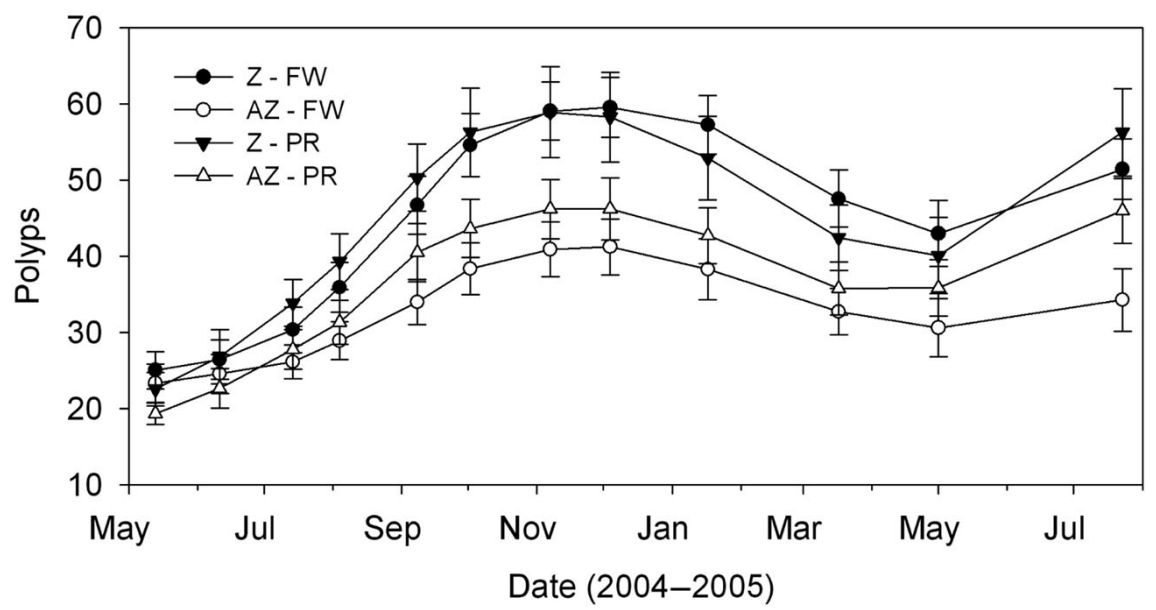

Fig. 4. Astrangia poculata. Mean $( \pm \mathrm{SE})$ number of polyps per colony over time. PR: Pettaquamscutt River; FW: Ft. Wetherill; Z: zooxanthellate corals; AZ: azooxanthellate corals 


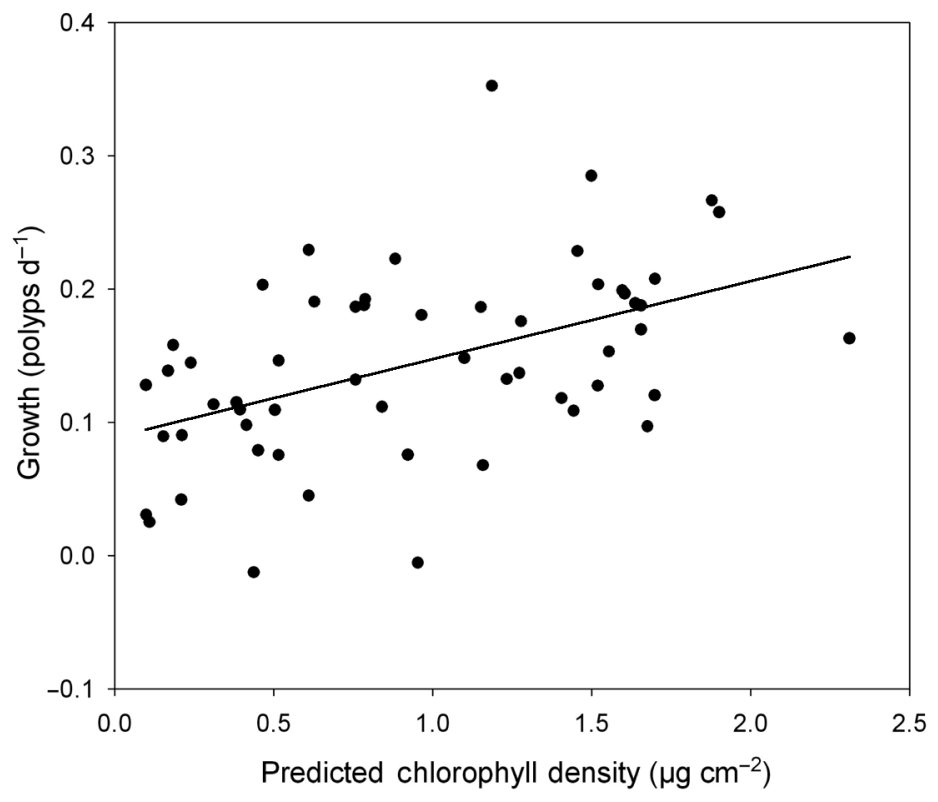

Fig. 5. Astrangia poculata. Predicted chlorophyll density versus growth rate for all corals, based on means for the $8 \mathrm{mo}$ of net growth (May to December) ( $\mathrm{n}=56 ; y=0.0586 x+$ $\left.0.0888 ; \mathrm{R}^{2}=0.23 ; \mathrm{p}<0.001\right)$

temperature dependence of calcium carbonate deposition rates reported by Jacques et al. (1983) closely match the polyp budding rates measured in the present study, and the differences between zooxanthellate and azooxanthellate rates are similar.

\section{DISCUSSION}

\section{Chlorophyll density estimation}

Coral pigmentation measured from digital images reflected a strong non-linear relationship with chlorophyll density in Astrangia poculata. The curvilinear shape of the function suggests that estimates of chlorophyll density at low polyp color values may be less reliable, and this could be partially responsible for the higher standard errors among azooxanthellate corals. However, significant autocorrelation of both azooxanthellate time series suggests that these data are well represented ${ }_{i}$ this autocorrelation may have benefited from the use of a repeated-measures design as opposed to random collections. Thieberger et al. (1995), who first developed the photographic technique linking coral color to chlorophyll density, obtained similar color-chlorophyll relationships for 3 tropical coral species in the Red Sea. Maguire et al. (2002) and Edmunds et al. (2003) adapted the technique for digital images and software that could measure color in the RGB spectrum.
The use of chlorophyll density over zooxanthella density as a symbiosis parameter was chosen for this study due to seasonal fluctuations in chlorophyll content per zooxanthella cell (i.e. photoadaptation) that have been observed in tropical corals (Brown et al. 1999, Fitt et al. 2000, Warner et al. 2002) as well as in Astrangia poculata (Cummings 1983). Such fluctuations preclude the use of a single relationship between color and zooxanthella density, obtained at any one time of year, to make estimates of zooxanthella density over time. Despite the advantages of a color-chlorophyll curve, the limitation is that it cannot distinguish the contribution of changes in zooxanthella density versus changes in zooxanthella pigment content to polyp pigmentation. Additionally, these non-destructive methods cannot account for variations in tissue mass that add a third dimension to any measure of symbiosis on an areal basis.

\section{Temporal variation in coral pigmentation}

Nearly all corals, regardless of their initial symbiotic state, underwent some degree of temporal change in pigmentation. However, the trend among zooxanthellate corals, with high pigmentation occurring during late summer/early autumn and subsequent lows during winter and spring, are most indicative of a seasonal cycle. In spite of coarse temporal resolution, 5 random coral collections from PR by Cummings (1983) over a 1 yr period suggested similar zooxanthella density and tissue mass patterns. Chlorophyll a per cell, conversely, was highest in winter and spring and lowest in summer and fall (Cummings 1983). Taken together, the 2 patterns appear to concur with the pigmentation patterns for zooxanthellate corals in the present study. For example, the stable to very slow reduction in pigmentation observed during the winter months may be the result of an increase in cell-specific chlorophyll that could compensate for the potential loss in pigmentation from a reduction in zooxanthella densities. Additionally, the somewhat dramatic reduction in pigmentation among both zooxanthellate and azooxanthellate corals (except for PR zooxanthellate corals) in July 2004 may reflect a drop in cell-specific chlorophyll associated with the longest and most intense days of sunlight of the year. Alternatively, this temporary loss of color could be interpreted as an increase in tissue mass, perhaps accompanied by a lag in zooxanthella growth that essentially dilutes coral pigmentation until the new coral cells become occupied by symbionts in subsequent months.

Studies of tropical scleractinians indicate that temperature is perhaps the most important driver of seasonal cycles in pigmentation and symbiont density 


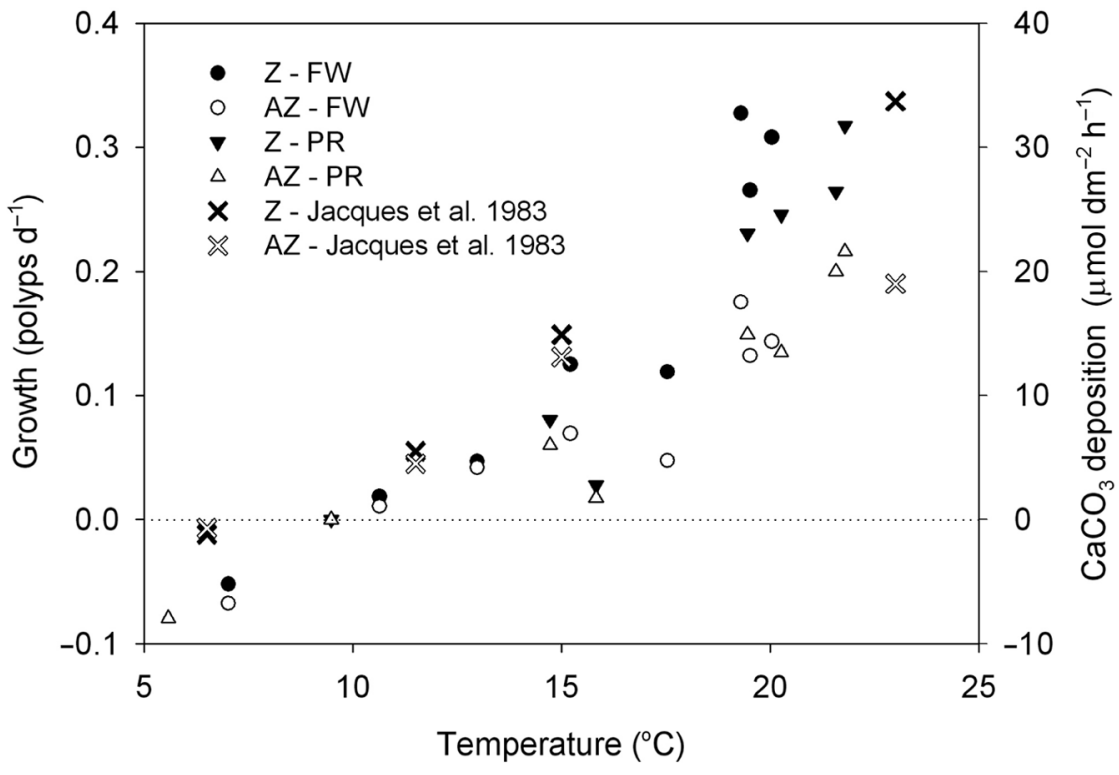

Fig. 6. Astrangia poculata. Temperature versus coral growth: polyp budding rates from the present study compared with laboratory calcium carbonate deposition rates from Jacques et al. (1983). For polyp budding data, each point represents the mean growth and temperature for 1 mo sampling intervals. Values $<5^{\circ} \mathrm{C}$ and -0.1 polyps $\mathrm{d}^{-1}$ were excluded from the graph. PR: Pettaquamscutt River; FW: Ft. Wetherill; Z: zooxanthellate corals; AZ: azooxanthellate corals

(Brown et al. 1999, Fitt et al. 2000), and Astrangia poculata appears to be no exception. The positive linear response of zooxanthella photosynthesis to temperature (Jacques et al. 1983) and the resulting effect on the algal population growth rate is probably largely responsible for seasonal pigmentation trends. Although zooxanthella photosynthesis may be negligible below $5^{\circ} \mathrm{C}$ (Jacques et al. 1983), zooxanthellae appear to build up chlorophyll for the low light of winter (Cummings 1983) and even divide in spite of low temperatures (J.D. unpubl. data). Laboratory incubations suggest that although zooxanthella mitotic rates in hospite are nearly 3 times higher at summertime temperatures $\left(20^{\circ} \mathrm{C}\right.$ in September), division nonetheless occurs at $3^{\circ} \mathrm{C}$ in March (J.D. unpubl. data). During warmer months, increased coral tissue biomass (Cummings 1983, J.D. pers. obs.) is likely to support more zooxanthellae and thus further enhance pigmentation (see Fitt et al. 2000). Variations in tissue mass from month to month were clear though nonquantifiable from coral images, with a trend very similar to coral pigmentation. Since $A$. poculata is capable of metabolic regulation at the higher range of temperatures (11 to $23^{\circ} \mathrm{C}$; Jacques et al. 1983), energy allocation to tissue growth should increase with temperature.

In contrast to the temporal pigmentation trends reported here for zooxanthellate Astrangia poculata, zooxanthella and chlorophyll density among tropical scleractinians tend to be highest during the coolest times of year and lowest during the warmest periods (Stimson 1997, Brown et al. 1999, Fitt et al. 2000, but see Costa et al. 2005). This may relate to the generalization that corals and their symbionts in the tropics are living closer to their upper rather than their lower thermal tolerance threshold, while the opposite is true of A. poculata and probably other temperate scleractinians. Seasonal depressions of zooxanthellae and their pigments in the tropics can be driven by 2 different factors: (1) an increase in both host and symbiont respiratory metabolism with higher temperatures that reduces both host tissue mass and algal density, and (2) excessive thermal and/or irradiance stress, which causes photoinhibition and photodamage in zooxanthellae, a phenomenon more typically associated with severe coral bleaching (Fitt et al. 2001). Seasonal reductions in A. poculata pigmentation may not be as extreme as in tropical corals due to cold-suppression of metabolism in both host and symbiont (Jacques et al. 1983), but it is plausible that photoinhibition also plays a role in reducing zooxanthella densities at low temperatures, since low and high temperature photoinhibition share similarities (Gombos et al. 1994, Warner et al. 1999).

Seasonal irradiance cycles ultimately drive air and water temperatures, but they also influence zooxanthella photosynthetic processes (Warner et al. 2002) and therefore act as additional drivers of coral pigmentation cycles (Stimson 1997, Brown et al. 1999, Warner et al. 2002). It is expected that corals received photosynthetically active radiation (PAR) levels within the range predicted by Narragansett Bay light extinction coefficients (Oviatt et al. 2002), which fall within the 
same range of saturating irradiance for photosynthesis in Astrangia poculata symbionts $\left(120 \mu \mathrm{mol}\right.$ quanta $\mathrm{m}^{-2}$ $\mathrm{s}^{-1}$ at $15^{\circ} \mathrm{C}$ up to $400 \mu \mathrm{mol}$ quanta $\mathrm{m}^{-2} \mathrm{~s}^{-1}$ at $23^{\circ} \mathrm{C}_{\text {; }}$ Jacques et al. 1983). Typical surface irradiance in Rhode Island peaks in June and reaches its minimum in December (Pilson 1985), meaning that pigmentation in A. poculata is associated with the moderate irradiance levels of the late summer and early fall. It is therefore hypothesized that irradiance influences the seasonal patterns of pigmentation in A. poculata primarily through photoadaptation effects on algal cell chlorophyll content (Cummings 1983) rather than through the photodamage effects associated with the high irradiance levels of the tropical spring and summer (Gorbunov et al. 2001, Warner et al. 2002). However, seasonal variations in water-column light attenuation may add an important caveat; for example, water clarity in the region is typically highest during the colder months, when surface irradiance is relatively low, and vice versa (J.D. pers. obs.).

Pigmentation trends in azooxanthellate Astrangia poculata colonies were not analogous to zooxanthellate corals. Most notable is the lack of an early autumn peak in color and an overall increase in pigmentation that was subtle at FW but marked at PR. Despite initially low pigmentation among all azooxanthellate corals at the beginning of the study, all but 3 out of 27 azooxanthellate corals gained at least some pigmentation at some point over the course of a year. Some of this variability may be attributed to manipulation effects and removal of the algal canopy, which may have increased corals' original light and/or temperature (in the case of transplantation from FW to $\mathrm{PR})$ regime. Since many azooxanthellate corals are in fact inhabited by small zooxanthella populations that are below visual detection densities and even standard hemocytometer count detection densities (J.D. unpubl. data), presumably, changes in light or temperature could readily trigger increases in symbiont density. While some azooxanthellate corals may have responded to a higher light environment, the considerable increase in pigmentation among PR azooxanthellate corals compared to a more subtle increase among FW corals suggests that other factors, such as temperature, may have been more influential.

Asynchrony in the pigmentation and growth trends of both zooxanthellate and azooxanthellate corals between the study sites is likely a reflection of the dissimilar environmental regimes. In the Pettaquamscutt River, an ebb tide apparently released turbid water that caused increased light attenuation. This water, having been entrained in a relatively shallow estuary averaging $2 \mathrm{~m}$ in depth, was either warmed or cooled relative to Rhode Island Sound water depending on the season. Zooxanthellate corals at PR reached their maximum pigmentation at least 1 mo before those at FW, perhaps a result of higher summertime temperatures in the river. In addition, as mentioned above, PR azooxanthellate corals underwent a substantial increase in pigmentation during the study period that was not observed at FW. In spite of a chronically reduced irradiance regime, PR may be an especially favorable environment for symbiosis due to prolonged higher temperatures. Randomized coral collections by Cummings (1983) from the Pettaquamscutt River suggested a higher prevalence of symbiosis compared to sites in Narragansett Bay and Rhode Island Sound, and personal observations (by J.D.) support these data. Temperatures at $\mathrm{PR}$ exceeded the $15^{\circ} \mathrm{C}$ threshold for $22 \mathrm{~d}$ longer than they did at $\mathrm{FW}$ and averaged $>4^{\circ} \mathrm{C}$ warmer at their maximum, so it is possible that at PR, the high prevalence of zooxanthellate corals, the increase in pigmentation among azooxanthellate corals, and the earlier peak in growth and pigmentation are reflective of these differences.

\section{Temporal variation in coral growth and relation to pigmentation}

Similarly to coral pigmentation trends, growth of Astrangia poculata showed considerable seasonal variation. The results of this field study corroborate with the laboratory measurements of Jacques et al. (1983) and show that skeletal growth at this northern margin of the coral's range is limited to the approximately $8 \mathrm{mo}$ between April and December. The present study, however, documents an important ecological observation: the inactivity of corals during the coldest periods of the year results in their inability to avoid sedimentation and settlement of any bare skeleton by other organisms, which leads to tissue loss particularly around the edges of the colony. Tissue re-growth in the spring can occur, but only in calices that remain mostly bare, while areas of the skeleton settled by other organisms are permanently lost. These processes may help to explain the northern range limit of this coral. Cape Cod acts as a well-defined barrier between waters fed by the Labrador Current to the north and the Gulf Stream to the south. Temperatures north of Cape Cod reach similar seasonal lows as southern New England, but do not reach $20^{\circ} \mathrm{C}$ during the warm season, and it is therefore hypothesized that corals settling north of the cape would struggle to grow enough in the warm season to overcome partial colony loss during the winter. However, this hypothesis allows that $A$. poculata would not first be overcome by reproductive or developmental limitations.

Zooxanthella photosynthesis significantly enhances calcium carbonate deposition in symbiotic scleractini- 
ans (Jacques et al. 1983, Gattuso et al. 1999). This symbiosis effect is apparent in the higher polyp budding rates of initially zooxanthellate Astrangia poculata, as well as in the significant relationship between pigmentation and growth rate over the growing season. Given that enhanced calcification in zooxanthellate corals has been questioned by recent studies (Marshall 1996, Marshall \& Clode 2004), the present study offers unequivocal field documentation of symbiosis enhancement within a single scleractinian species. However, because the relationship described only $23 \%$ of the variation in growth rate, it is expected that other factors such as food intake (Szmant-Froelich \& Pilson 1984, Miller 1995), microhabitat differences, and individual genotypic variation also contributed to overall variability in growth. Since A. poculata may obtain benthic prey as a substantial proportion of its food (Grace 1996), prey capture for an individual colony could be more spatially and temporally variable than it would be if prey were predominantly planktonic. Additionally, if enhancement of calcification by zooxanthella photosynthesis in A. poculata occurs only at temperatures of approximately $15^{\circ} \mathrm{C}$ and above (Jacques et al. 1983), symbiosis would have an effect on growth for only 4 (FW) to 5 (PR) of the approximately 8 mo of growth. At deeper depths, the rapid attenuation of PAR severely limits the benefits and extent of symbiosis (Weston 1980, Jacques et al. 1983) and the role of heterotrophy becomes more critical.

Acknowledgements. J.D. is indebted to J. Barber for field assistance. In addition, the authors thank the following people for advice and/or assistance: M. Boller, P. Edmunds, S. Grace, M. Gustafson, B. Longval, G. Moeser, J. Ritchie, R. Rotjan, K. Sebens, J. Sylvester, and L. Trueblood. Valuable feedback on earlier versions of the manuscript was provided by C. Oviatt, M. Pilson, B. Siebel, and 3 anonymous reviewers. This study was supported by an American Academy of Underwater Sciences student scholarship to J.D., as well as by the URI Department of Biological Sciences, and National Science Foundation grants to E.C.

\section{LITERATURE CITED}

Baghdasarian G, Muscatine L (2000) Preferential expulsion of dividing algal cells as a mechanism for regulating algal-cnidarian symbioses. Biol Bull (Woods Hole) 199: 278-286

Brown BE, Dunne RP, Ambarsari I, Le Tissier MDA, Satapoomin U (1999) Seasonal fluctuations in environmental factors and variation in symbiotic algae and chlorophyll pigments in four Indo-Pacific coral species. Mar Ecol Prog Ser 191:53-69

Cohen AL, Owens KE, Lane GD, Shimizu N (2002) The effect of algal symbionts on the accuracy of $\mathrm{Sr} / \mathrm{Ca}$ paleotemperatures from coral. Science 296:331-333

Costa CF, Sassi R, Amaral FD (2005) Annual cycle of symbiotic dinoflagellates from three species of scleractinian corals from coastal reefs of northeastern Brazil. Coral Reefs 24:191-193
Cummings C (1983) The biology of Astrangia danae. PhD dissertation, University of Rhode Island, Kingston

Edmunds PJ, Gates RD, Gleason DF (2003) The tissue composition of Montastrea franksi during a natural bleaching event in the Florida Keys. Coral Reefs 22:54-62

Fagoonee I, Wilson HB, Hassell MP, Turner JR (1999) The dynamics of zooxanthellae populations: a long-term study in the field. Science 283:843-845

Fitt WK, McFarland FK, Warner ME, Chilcoat GC (2000) Seasonal patterns of tissue biomass and densities of symbiotic dinoflagellates in reef corals and relation to coral bleaching. Limnol Oceanogr 45:677-685

Fitt WK, Brown BE, Warner ME, Dunne RP (2001) Coral bleaching: interpretation of thermal tolerance limits and thermal thresholds in tropical corals. Coral Reefs 20:51-65

Gattuso JP, Allemand D, Frankignoulle M (1999) Photosynthesis and calcification at cellular, organismal, and community levels: a review on interactions and control by carbonate chemistry. Am Zool 39:160-183

Gombos Z, Wada H, Murata N (1994) The recovery of photosynthesis from low-temperature photoinhibition is accelerated by the unsaturation of membrane lipids: a mechanism of chilling tolerance. Proc Natl Acad Sci USA 91: 8787-8791

Gorbunov MY, Kolber ZS, Lesser MP, Falkowski PG (2001) Photosynthesis and photoprotection in symbiotic corals. Limnol Oceanogr 46:75-85

Grace SP (1996) The effects of water flow on Astrangia poculata. MS thesis, University of Rhode Island, Kingston

Grace SP (2004) Ecomorphology of the temperate scleractinian Astrangia poculata: coral-macroalgal interactions in Narragansett Bay (Rhode Island). PhD dissertation, University of Rhode Island, Kingston

Jacques TG, Pilson MEQ (1980) Experimental ecology of the temperate scleractinian Astrangia danae. I. Partition of respiration, photosynthesis, and calcification between host and symbionts. Mar Biol 60:167-178

Jacques TG, Marshall N, Pilson MEQ (1983) Experimental ecology of the temperate scleractinian Astrangia danae. II. Effect of temperature, light intensity and symbiosis with zooxanthellae on metabolic rate and calcification. Mar Biol 76:135-148

Jeffrey SW, Humphrey GF (1975) New spectrophotometric equations for determining chlorophylls $a, b, c 1$, and $c 2$ in higher plants, algae and natural phytoplankton. Biochem Physiol Pflanz 167:191-194

Johannes RE, Wiebe WJ (1970) A method for determination of coral tissue biomass and composition. Limnol Oceanogr 15:822-824

Maguire B, Gleason DF, Mojica R, Mojica EC (2002) Changes in photographic $R, G$, and $B$ numerical values quantitatively reflect pigment and zooxanthella decrease during Porites astreoides bleaching. In: Kasim Moosa MK, Soemodihardjo S, Nontji A, Soegiarto A, Romimohtarto K, Sukarano, and Suharsono (eds) Proc 9th Int Coral Reef Symp. International Coral Reef Society, Bali, p 1129-1138

Marsh JA (1970) Primary productivity of reef-building calcareous red algae. Ecology 51:255-263

Marshall AT (1996) Calcification in hermatypic and ahermatypic corals. Science 271:637-639

Marshall AT, Clode P (2004) Calcification rate and the effect of temperature in a zooxanthellate and an azooxanthellate reef coral. Coral Reefs 23:218-224

Miller MW (1995) Growth of a temperate coral: effects of temperature, light, depth, and heterotrophy. Mar Ecol Prog Ser 122:217-225

Miller MW, Hay ME (1996) Coral-seaweed-grazer-nutrient 
interactions on temperate reefs. Ecol Monogr 66:323-344

Muller-Parker G, Davy SK (2001) Temperate and tropical seaanemone symbioses. Invertebr Biol 120:104-123

Muscatine L (1990) The role of symbiotic algae in carbon and energy flux in reef corals. In: Dubinsky Z (ed) Ecosystems of the world, Vol 25. Coral reefs. Elsevier, Amsterdam

Oviatt C, Keller A, Reed L (2002) Annual primary production in Narragansett Bay with no bay-wide winter-spring phytoplankton bloom. Estuar Coast Shelf Sci 54: 1013-1026

Peters EC, Pilson MEQ (1985) A comparative study of the effects of sediment on symbiotic and asymbiotic colonies of the coral Astrangia danae Milne Edwards and Haime, 1849. J Exp Mar Biol Ecol 92:215-230

Peters EC, Cairns SD, Pilson MEQ, Wells JW, Jaap WC, Lang JC, Vasleski CE, St. Pierre Gollahon L (1988) Nomenclature and biology of Astrangia poculata (=A. danae, $=A$. astreiformis) (Cnidaria: Anthozoa). Proc Biol Soc Wash 101:234-250

Pilson MEQ (1985) Annual cycles of nutrients and chlorophyll in Narragansett Bay, Rhode Island. J Mar Res 43:849-873

Schiller C (1993) Ecology of the symbiotic coral Cladocora caespitosa (L.) (Faviidae, Scleractinia) in the Bay of Piran (Adriatic Sea). II. Energy budget. PSZN I: Mar Ecol 14: 221-238

Schuhmacher H, Zibrowius H (1985) What is hermatypic? A redefinition of ecological groups in corals and other organisms. Coral Reefs 4:1-9

Stimson J (1997) The annual cycle of density of zooxanthellae in the tissues of field and laboratory-held Pocillopora

Editorial responsibility: Charles Birkeland (Contributing Editor), Honolulu, Hawaii, USA damicornis (Linnaeus). J Exp Mar Biol Ecol 214:35-48

Szmant-Froelich A, Pilson MEQ (1980) The effects of feeding frequency and symbiosis with zooxanthellae on the biochemical composition of Astrangia danae Milne Edwards and Haime, 1849. J Exp Mar Biol Ecol 48:85-97

Szmant-Froelich A, Pilson MEQ (1984) Effects of feeding frequency and symbiosis with zooxanthellae on nitrogen metabolism and respiration of the coral Astrangia poculata. Mar Biol 81:153-162

Szmant-Froelich A, Yevich P, Pilson MEQ (1980) Gametogenesis and early development of the temperate coral Astrangia danae (Anthozoa: Scleractinia). Biol Bull (Woods Hole) 158:257-269

Thieberger Y, Kizner Z, Achituv Y, Dubinsky Z (1995) A novel, nondestructive bioassay for assessing areal chlorophyll $a$ in hermatypic cnidarians. Limnol Oceanogr 40: 1166-1173

Underwood AJ (1997) Experiments in ecology: their logical design and interpretation using analysis of variance. Cambridge University Press

Warner ME, Fitt WK, Schmidt GW (1999) Damage to photosystem II in symbiotic dinoflagellates: a determinant of coral bleaching. Proc Natl Acad Sci USA 96:8007-8012

Warner ME, Chilcoat GC, McFarland FK, Fitt WK (2002) Seasonal fluctuations in the photosynthetic capacity of photosystem II in symbiotic dinoflagellates in the Caribbean reef-building coral Montastrea. Mar Biol 141:31-38

Weston MP (1980) Distribution of the dinoflagellate symbiosis in Astrangia danae as affected by light attenuation. MS thesis, Old Dominion University, Norfolk

Submitted: December 27, 2006; Accepted: May 8, 2007

Proofs received from author(s): September 24, 2007 